cyanoethylene derivatives were discussed comparing with those of bibenzyl derivatives described before by NISHIZUKA et al (Trans. Soc. Path. Jap. 40(Ed. Reg.) : 274, 1951, idem. 41 (Ed. Reg.) $41: 73$, 1952). And it is revealed that the necessary conditions of the chemical structure in the former group in order to exhibit biological action differ from those in the latter. In rats treated with the former estrogens, more prominent proliferation of the endometrial tissues, more intense hypertrophy of the adrenal cortex and less atrophic changes in the parenchymal tissues of the ovary were found microscopically than those in rats treated with estradiol and hexestrol.

\title{
Study on the Urinary Gonadotropin in Patients with Endocrine Disorders.
}

\author{
Kenji MOTOHASHI
}

Prof. Okinaka's Clinic, School of Medicine, Univ. of Tokyo.

\section{Summary}

Gonadotropin (GTP) in 24 hours urine was assayed in patients with endocrine disorders hospitalized in our clinic during the last two years. For the extraction of GTP from the urine, Bradbury's method was used. For the bioassay, mouse uterine-weight method was used. Following results were obtained.

1) In eight patients with panhypopituitarism, including three pituitary dwarfs, the values were low, but normal value was obtained in a case with idiopathic diabetes insipidus.

2) One of the two acromegalic patients secreted high value of GTP, and another case showed low value. In a patient with precocious puberty high value was obtained. In this patient urinary GTP demonstrated strong effect of ICSH.

3) Normal or subnormal levels were observed in all three cases of Cushing's syndrome. In a case of Addison's disease, low value was observed.

4) Normal value was observed in a case of primary myxedema.

5) Among the cases of male hypogonadism, one showed normal value, and the other three cases low values. Two eunuchs showed high values.

6) The urinary GTP in patients who received atomic radiation at Bikini had high biological activity. In all of these cases the spermatogenesis was intensively disturbed, but low urinary 17KS level was obtained only in a few cases.

These results shows that urinary GTP assay by this method is useful to determine one aspect of pituitary function, but the differentiation between the lower normal value and abnormally low value is not so easy. Further improvement of this method should be expected.

\section{One Case of Scleroderma Diffusum}

\author{
By
}

\section{Eishiro YAMADA, Masao FUKUSHIMA, Maasamitsu OGURI, Kazunari OKITSU, Keiko FURUHASHI}

The Third Department of Internal Medicine, Nagoya, University School of Medicine.

(Director: Prof. Dr. Kozo Yamada)

Since the concept of collagen disease was established by Klemperer and his associates in 1942, sclero-

Vol. 33 No. 4 
derma diffusum has also been considered to be under that category. However, concerning the treatment of that disease many problem are yet remained.

The authors had recently a 42 year-old female patient of scleroderma diffusum with stiffening of skin and pigmentation in the extremities. Since conceptions of occurence of this disease expressed up to this day and various methods of treatment were examined by the authors, and this patient could be observed for a long period, this report was presented.

Methods of treatment are as follows;

(1) Administration of Meticorten and Predonine.

(2) Transplantation of the suprarental body and the hypophysis.

(3) Administration of Hyaluronidase and Chondroitin sulfate.

(4) Vitamines, especially C and D.

(5) Penicillin.

Now, under the present state that the chief symptom of this disease is that appeared mainly in the skin and there is found no symptom by which pathological conditions can be certainly grasped, objective estimation of treatment effects is extremely difficult. Moreover, observing the progress of this disease it can not be cured by only one treatment. Therefore, combined used of various methods is desirable. Also in our case above mentioned methods were all used and Meticorten, Hyaluronidase and Penicillin are thought to have been most effective.

\section{Study of the Treatment for Hyperthyroidism with Radioisotop $\mathrm{I}^{131}$}

\section{N. KUSUNOKI, T. IBA, K. KATO, T. MASUDA}

Depart. of Surgery School of Medicine, Hiroshima University. (Prof. R. Uemura, M.D.)

The result of treatment with $27-434 \mu \mathrm{c} / \mathrm{g}$ of radioisotop $\mathrm{I}^{\mathbf{1 3 1}}$ on hyperthyroidism is as follows.

On first administration, $88.8 \%$ of male and $91.8 \%$ of female healed. Including, however, second administration the result reversed, namely, greater number of female result in healing than male.

Both P.B.I. and B.M.R. reduced proportionately to after adminisration of $\mathrm{I}^{131}$.

Before institution, comparing a up-take value of $1 \mathrm{hr}$ with of $24 \mathrm{hrs}$, first one showing more close relation than later. This relationship becomes rather rough after administration.

Vit. G in blood is extremely high or low before administration, but this returned to normal level after.

In relationship' between total protein and $\mathrm{I}^{131}$ no significance obtained. Of electropholetic analysis of protein, however, the amount of $\gamma$-globulin increased after $\mathrm{I}^{\mathbf{1 3 1}}$ given.

These above observation lead us to the conclusion, that in order to make exact diagnosis of Hyperthyroidism not one, but several test should be carried out simultaneously. 
琗皮症は1634年 Zacutus Lusitanus により記載された疾患で，始めは単なる皮膚疾患と考えられていた が，1942年 Klemperer ${ }^{11)}$ 等が皮膚慗原病なる概念を打立てて以来，汎発性琗皮症もその範疇に属する疾患と

\section{第 1 図治療前}

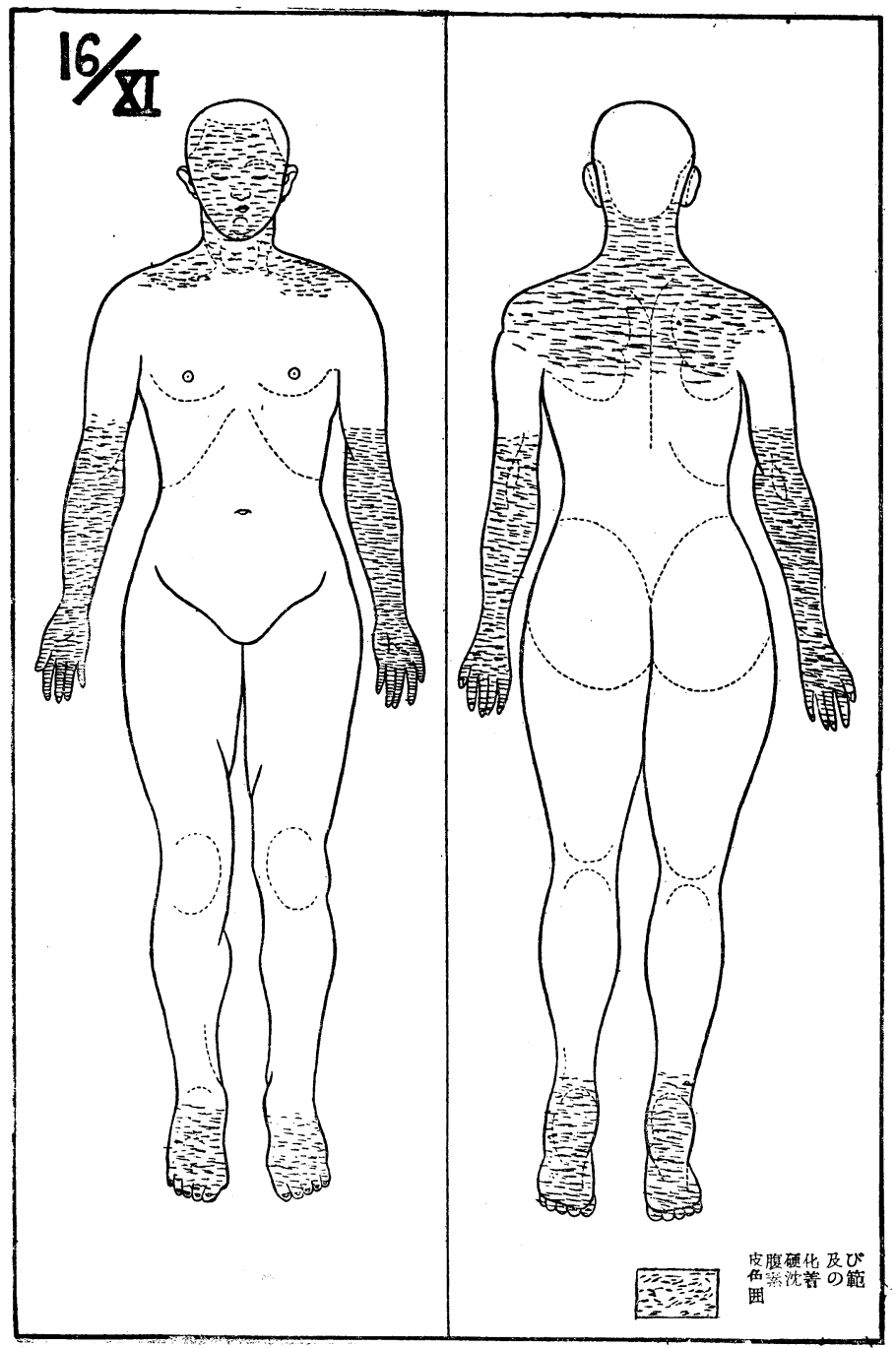

考えられつつある. 一方そ の発生原因に関しても，伝 染説, 血管一神経障碍説, 内 分泌腺異常説に始まり, 近 年では一部は適応の失調に， 一部は Homeostasis の失 衡にその根拠を求めるなど と現在尚統一的な解明には ほど遠い，従つてその治療 面に扑いても, 経験より発 したもの, 種々の病因論或 は病座観より出発した治療 法があり確害なものを見な いのは遺憾である2).

我々は今回一例の汎発性 鞏皮症と思われる思者を経 験したので, 前述の概念及 び発生原因を顧慮し，夫々 の治療法に梌討を加えつつ 臨床症状の特徵と治療との 関連，経過をむとめて報告 する。

症 例 $\mathrm{M} \cdot \mathrm{T}$, 女, 42 才, 主婦.

家族歴 特記すべきもの はない。

䠶往歴 22才時急性卵管 炎に罹患. 23才時には梅毒 に感染し Salvarsan 治療 を受けている，25才には早 産，28才には子宮外妊娠手 術を行つている, 
治療後

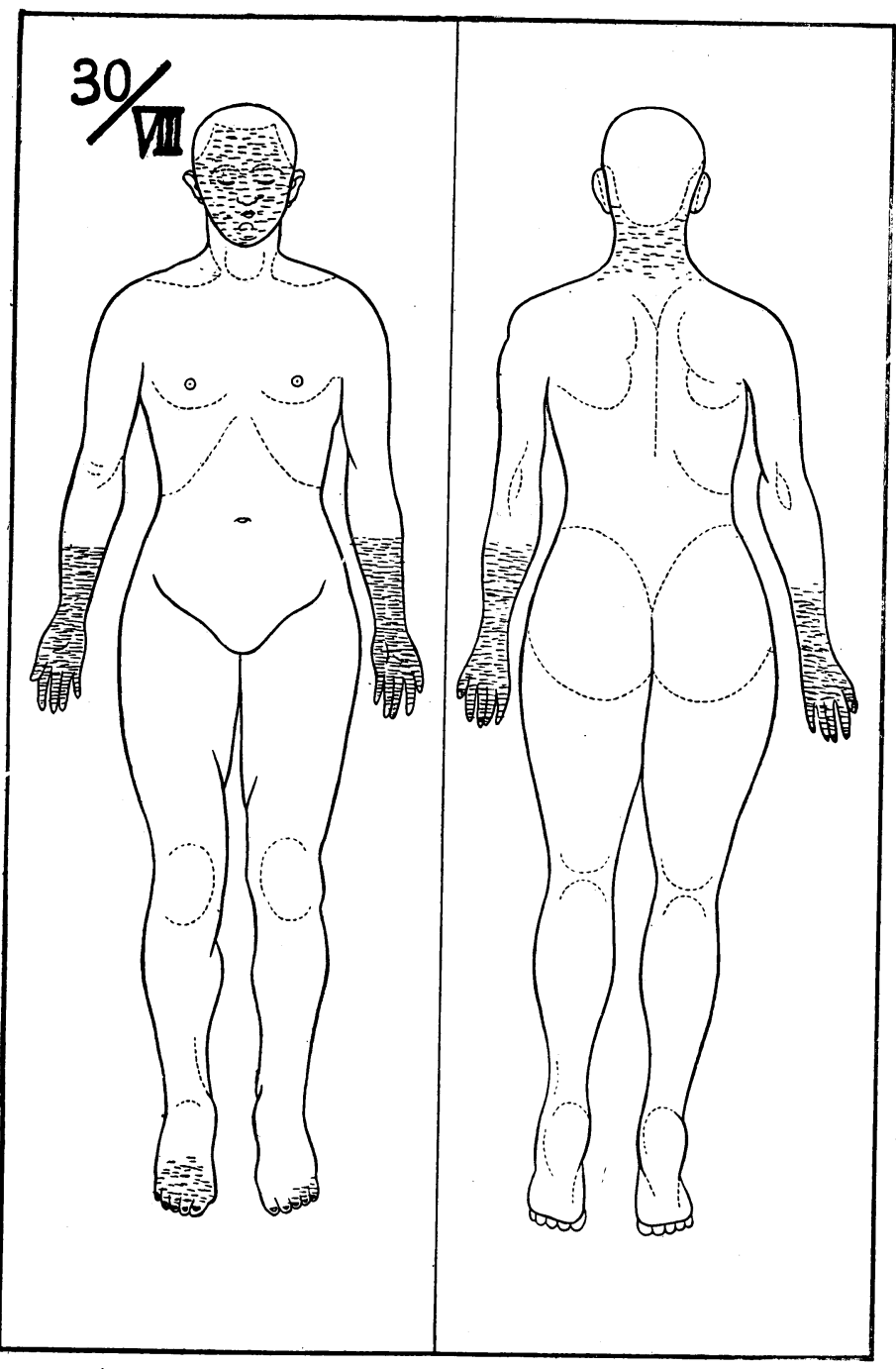

現病歴 昭和 30 年 2 月頃, 両側下腿に稍硬固な指圧に より軽い圧痕を生ずる浮腫 か現われ，某医よりは脚気 として治療を受けていたが 軽快することがなかつた。 その頃加ら顔面，上肢皮虞 の不快な緊張感觉覚え, 全 身倦急感も強く現われ，4 月頃には心悸京進も加わわ つてきたので心電図を撮つ たが異常なしといわれた。

7 月頃には両側手指の有痛 性強直感及びしびれ感市り， 皮膚の “こわばり”が堌強 し，物觉うまく握れ恕よう になつて来た。

某䛦療所では関節リウマ チスとして Irgapyrin 内服, Cortisone 注射を受けたが， 軽快するのみか寧ろ悪化の 傾向にあつた. 11月に入つ てからは皮膚は黒ずんだ光 沢を帯び, 皮膚硬化の程度 も中心部への進行を増し, 肩, 肘部及び手指の運動障 碍並びに疼痛が強度になつ たので11月15日当科に入院 した.

入院時所見 体格小, 顔 面は一様に黒ずんだ光沢を 有し，表情にそしく，口は

「掞ちよば口」である。頭髪には特に異常はないが, 腋毛, 恥毛は非常に少い，脈搏は整調, 呼吸は胸腹型で異 常ない，血圧は最高 170 , 最低80で高血圧であり，頭痛，睡眠障碍を訴える。喀痰，咳嗽中等度にあり，便通 は秘結しがちで，排尿には全然異常を認めない．皮虞の硬化及び色素沈着の範囲は第 1 図の如くであり，前 額部，煩部，両側前膊より指尖にがけての皮膚は板状硬化し，表面平滑で解譬を作り難い状態にあり光沢が ある．煩部，胸腹部も稍黒味を带び少し硬化している，肘関節は約30度しか屈曲せず，兩側指関節は強度の 屈曲を取り自動的，他動的に強く運動制限を有し，関節運動時及び自発的の疼痛を伴う，局所熱はない，爪 は萎縮性，爪床は貧血性である。

舌は湿潤で舌苔なく咽頭にも異常なく， 口腔粘膜の色素沈著はない. 甲状腺の腫張は認めず。打診すると 肺肝境界は第 5 肋間下端で心㵴濁音界は右に 1 横指左に 2 横指拡大している。心音は不純，しかし雑音を聴 取しない. 肺では両側後下部に乾性羅音を聴取する.胸部レントゲン写真をみると心臓陰影仙両側に拡大し， 肺紋理は増強しているが肺野に異常陰影を認めない，心電図にも著変を認めなかつた，肝，脾，腎，は触知 
し得ず，腱反射，皮膚反射共に正常．両手骨のレントゲン像には第 2 図の如く高度の萎縮像を見，指骨末端

第 2 図 雨側手骨レントゲン像

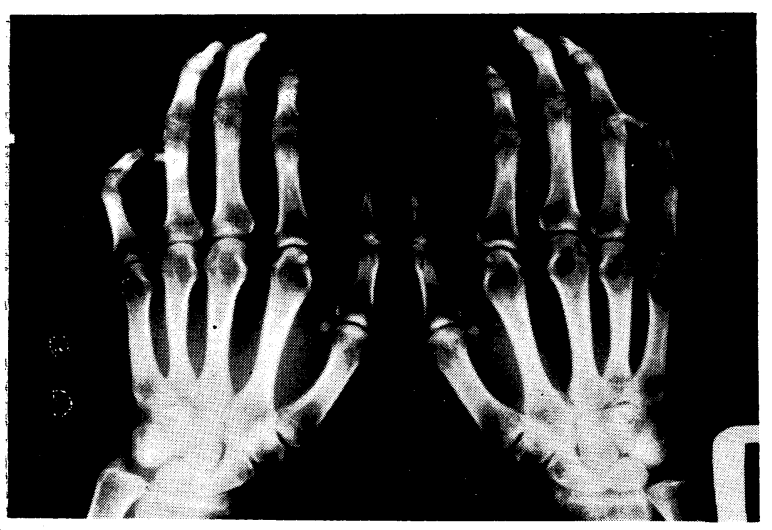

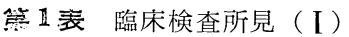

\begin{tabular}{|c|c|c|c|c|c|}
\hline 検 & 査 回 数 & 1 & 2 & 3 & 4 \\
\hline \multirow{3}{*}{ 血 } & $\mathrm{R} \times 10^{4}$ & 268 & 421 & 351 & 369 \\
\hline & $\mathrm{Hb} \%$ & 62 & 70 & 75 & 74 \\
\hline & $\mathrm{W}$ & 6800 & 7200 & 6800 & 5200 \\
\hline \multirow{4}{*}{ 像 } & $\mathrm{E} \%$ & 2 & 2 & 2 & 1.5 \\
\hline & $\mathrm{N} \%$ & 66 & 68 & 51 & 69.5 \\
\hline & $\mathrm{L} \%$ & 15 & 26 & 39 & 25.5 \\
\hline & $\mathrm{M} \%$ & 7 & 4 & 7 & 3.5 \\
\hline & 血沈值 $\begin{array}{c}(1 \text { 時間） } \\
\mathrm{mm}\end{array}$ & 12 & 12 & 10 & 14 \\
\hline 血 & 糖 mg/dl & 117.0 & 109.0 & & 102.7 \\
\hline \multirow{4}{*}{ 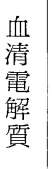 } & $\mathrm{Cl} \mathrm{mg} / \mathrm{dl}$ & 168.3 & 369 & 683 & \\
\hline & $\mathrm{Na} \mathrm{mg} / \mathrm{dl}$ & & 316 & 347 & 338 \\
\hline & $\mathrm{K} \quad \mathrm{mg} / \mathrm{dl}$ & & 18.6 & 22.5 & 15.0 \\
\hline & $\mathrm{Ca} \mathrm{mg} / \mathrm{dl}$ & & & 12.0 & 9.4 \\
\hline \multicolumn{2}{|r|}{ Thorn 試 験 \% } & -57 & & -58.3 & \\
\hline \multicolumn{2}{|r|}{ 血液梅毒 反 応 } & $(-)$ & & $(-)$ & $(-)$ \\
\hline \multirow{10}{*}{$\begin{array}{l}\text { 血 } \\
\text { 槳 } \\
\text { 蛋 }\end{array}$} & $\mathrm{T}-\mathrm{P} \quad \mathrm{g} / \mathrm{dl}$ & 7.72 & 8.04 & 8.63 & 8.11 \\
\hline & $\mathrm{g} / \mathrm{dl}$ & 2.83 & 3.35 & 4.52 & 3.63 \\
\hline & $\mathrm{g} / \mathrm{dl}$ & 4.06 & 3.60 & 3.59 & 3.41 \\
\hline & $\begin{array}{cc}\alpha & \mathrm{g} / \mathrm{dl}\end{array}$ & 1.06 & 0.94 & 1.03 & 1.49 \\
\hline & $\beta \quad \mathrm{g} / \mathrm{dl}$ & 1.02 & 1.24 & 1.13 & 0.85 \\
\hline & $\mathrm{g} / \mathrm{dl}$ & 1.98 & 1.41 & 1.43 & 1.07 \\
\hline & Fib & 0.83 & 1.09 & 0.52 & 1.07 \\
\hline & $\mathrm{A} / \mathrm{G}$ & 0.69 & 0.94 & 1.25 & 1.06 \\
\hline & $\gamma / \mathrm{G}$ & 0.48 & 0.38 & 0.4 & 0.31 \\
\hline & $\approx / \mathrm{A}$ & 0.70 & 0.4 & 0.31 & 0.31 \\
\hline
\end{tabular}

には骨溶解が見られた。トルコ鞍は 正常より全般に小であるが骨の変形 は見られなかつた。臨床検查成績は 大凡第 I 表（I）の 1 及び（II） の如くである. 即ち血液所見に於て は中等度の貧血, $\boldsymbol{\gamma}$ 一 グロブリンの 増加, A/G の逆転を認め, AGTH 25 単位筋注に上る 好酸球 減少率は - 57\%で正常であつた．血糖は比較 的高值を示し, 肝機能検查では高田 反応陽性, ブロムサルフアレン試験 軽度の排出遅延を見た。コレステリ ン值は大体正常. 䁈機能検査に於て は，GFR の軽度低下その他は正常 の下界にあり，基礎代謝率は $+28 \%$ で稍六進を示した。尚尿中 $17 \mathrm{KS}$ 排 泄は $4.9 \mathrm{mg} /$ day と著しく低值を示 し,第 3 図に見るように microscaleelution Chromatography 酒る分 劃測定では特に4，5分劃の低值を示 し, 性腺系ステロイドの減少をもの がたつている。

自律神経機能検查は交感神経緊張 型を呈し, 胃液は低酸度を示し, 検尿, 検便所見には異常を認めなかつた。

皮虚の組織検査に於ては, へマト キシリン・エオジン染色で表皮の萎 縮, 一部に異常角化を呈し, 乳頭消失, 膠原線維の肥大等を認訪てい. (第 4 図)

\section{治療並びに考按}

以上の症例定もつて我々は第 2 表 に挙げた治療を順次その経過に従つ て実施し, 治療の効果之臨床症状の 推移を観祭した。

1.メチコーテン及びプレドニン 最近の膠原病について共通の治療 として登場した下垂体一副腎皮質系 ホルモンは，鞏皮症の場合に於ける 内分泌失調説に対して劃期的な飛躍 を与え，その治療への試みは種々の 
第 1 表 臨床検査所見（I）

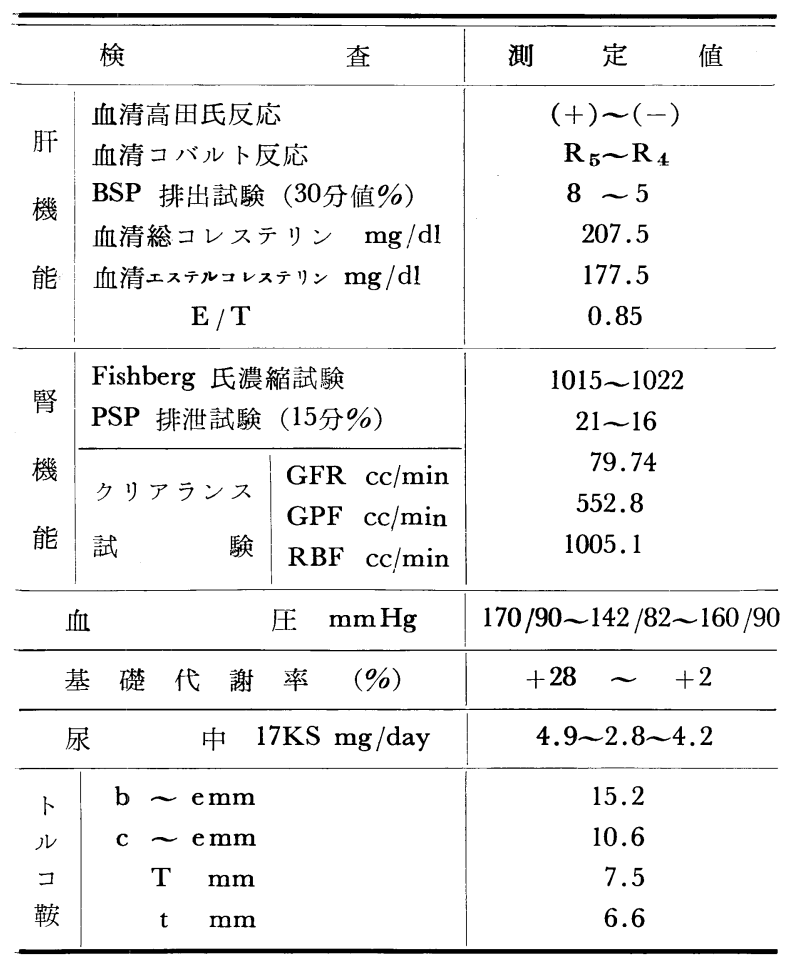

管3 図尿 $17 \mathrm{KS}$ 分劃

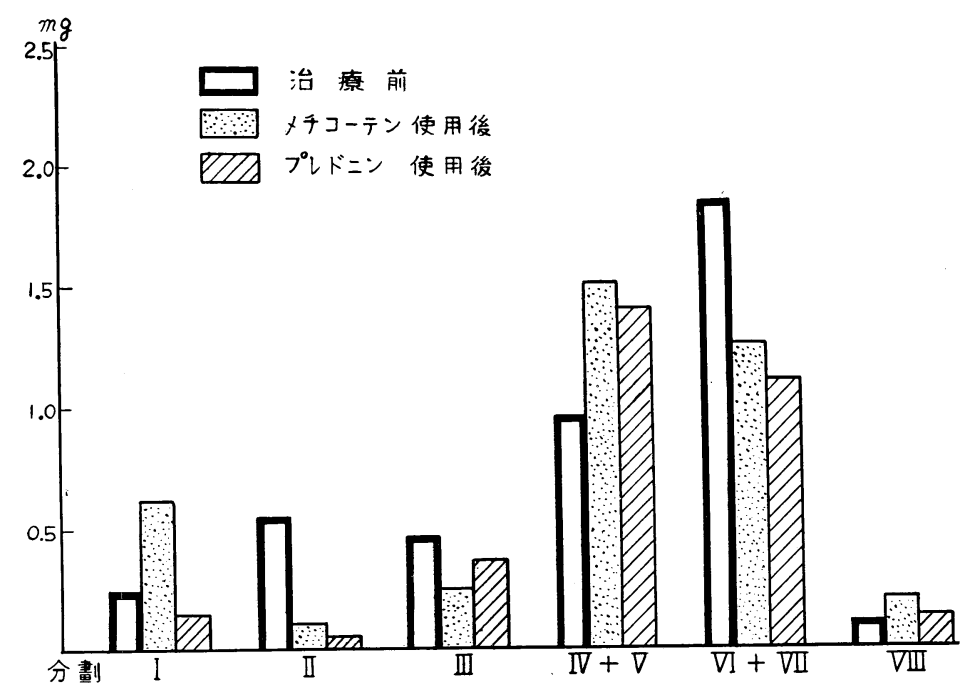

批判はありながら，難治とされてい た本症に対しても一つの光明を見出 し得たようである. 特に本症の場合, Sharnoff( ${ }^{3)}$, Steiner ${ }^{4)}$, Whittle 等はコ 一チゾンにより治療效果を認めてい るようであるが，それも矢張り症状 の根治には至らしめず，中止すれば 再発を見，その効果も初期に認め萎 縮期には無効のようである。本邦 ではこの種の治療による例は未だ少 くあるが, 川島5), 日野6), 倉田7) 等はその効果を認めているようであ る.

最近にこの種の薬剤でコーチゾン に比し抗口イマチス性及び抗炎症作 用がその $3 \sim 5$ 倍とされ，副作用な く使用量も $1 / 3$ 〜将で充分なるものと してメチコーテン, プレドニンなる ものが現われたので, 我々も最初は ィチコーテンを行つた所, 治療開始 㷋約 3 週間頃より頸部，鎖骨上窩附 近の皮膚は軟化し，顔面色素沈着の 軽減を見, 四肢の緊迫感, 関節部疼痛 及が浮腫は全く消失し， 第 1 表（I）の 2 亿見 るように入院当時の貧 血は恢復し $\mathrm{A} / \mathrm{G}, \boldsymbol{\gamma ー ク ゙ ~}$ ロブリンの改善が見ら れた。電解質に执いて は著変を見ない. 尚尿 中17KS の分劃測定值 は第3図に見る如く, その使用後にはIV, V 分劃の中等度增加を認 め, 性腺系スデロイド ホルモンの分泌増加を 来したと思われ，また VI, VII 分劃の著明な減 少はグリココルチコイ ドの分泌がそれによつ

て抑制されたと考えられた。

メチコーテンの場合，第 2 表つ 1 亿見るように最初の 10 日間は 1 日 $30 \mathrm{mg}$ ，以後は 1 日 $20 \mathrm{mg}$ を維持量とし て総量 $800 \mathrm{mg}$ の使用に終つたが，使用後漸次にして顔面浮腫感，乏尿を訴えたのでその後は塩化カリウムの 
第 4 図 治 療 前 皮膚 組 織 標 本

ヘマトキシリンエオジン染色

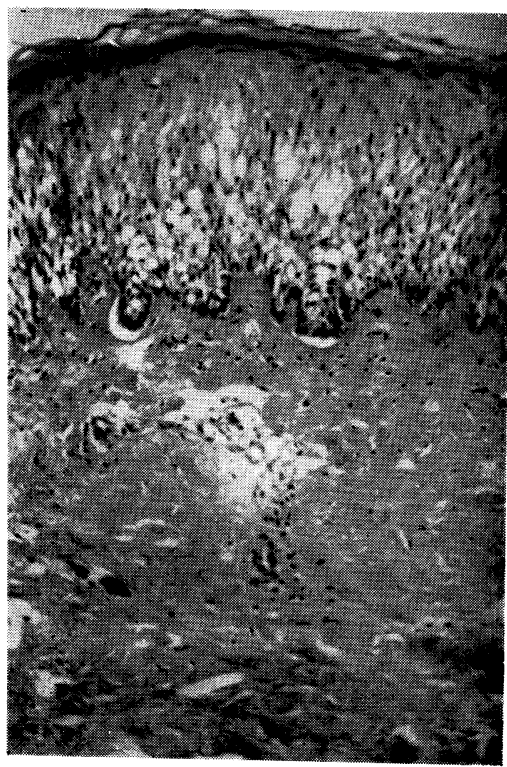

ワンギーソン染色

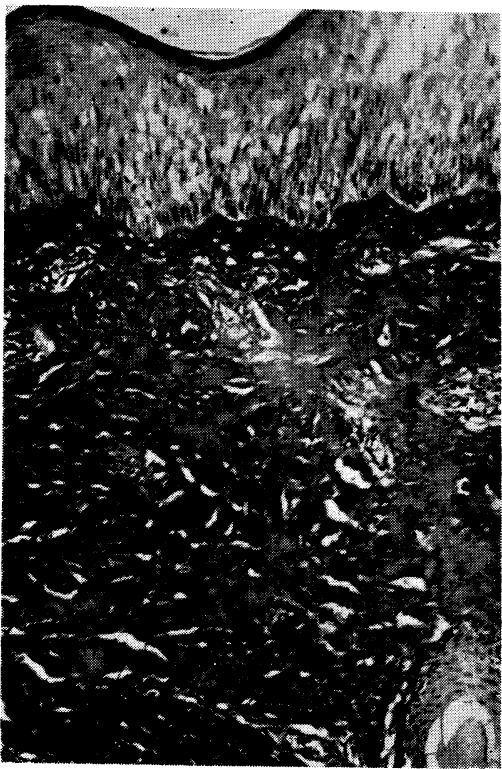

用を行つて見るべき副作用なく $800 \mathrm{mg}$ の服用を終了した。一方後日に使用したプレドニンでは前者の場合 程の明らかな自他覚的の変化を見ず，反つて副作用面のみ強く現われ，第 2 表 7 の最初の $20 \mathrm{mg}$ 服用時には 強度の不眠症に悩まされたので漸減して継続していつたが，両側前膊硬皮の部に異常多毛の現象が起つた。

第 2 表 望皮症患者治療の内容及び推移

1. Meticorten (総量 $800 \mathrm{mg}$ )

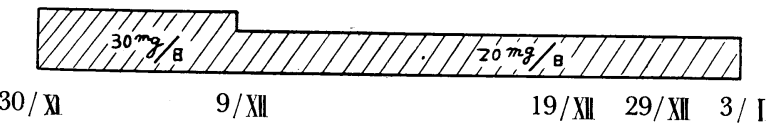

2. Chondroitin Sulfate (総量 $10 \mathrm{~g}$ )

$$
1 \mathrm{~g} / \text { 日 } 10 \text { 日間連用……7/ I 18/I }
$$

3. 副腎, 下垂体移植 $(29 / \pi)$

4. Hyaluronidase

$$
\left\{\begin{array}{l}
5 \% \text { glucose } 500 \mathrm{cc} \\
\text { Sprase } 5000 \text { 単位 } \\
\text { Corphyllin } 2 \mathrm{cc} \quad \text { 隔日 } 5 \text { 回皮下注射 }(26 / \mathrm{IV} \sim 1 / \mathrm{V})
\end{array}\right.
$$

5. Penicillin (総量1020万単位) + Hyaluronidase

$$
13 / \mathrm{V} \quad 24 / \mathrm{V} \quad 29 / \mathrm{V} \quad 4 / \mathrm{VI}
$$

1 日 P 60万笚位

Hy 5000 単位

6. Vitamin $\mathrm{D}+$ Vitamin $\mathrm{C}+$ Depo-Kallikrein

Vitamin D 10 万算位/隔日 $-21 / \mathrm{V} \sim 19 / \mathrm{VI}$ (15回)

Vitamin C $500 \mathrm{mg} /$ 日— $12 / \mathrm{V} \sim 27 / \mathrm{VII}$ (46回) （総量 $23.6 \mathrm{~g}$ ) 


\section{Depo-Kallikrein 40生物学的単位/日 - 20/V〜26/VII (20回)}

\section{Predonine (総量 $450 \mathrm{mg}$ )}

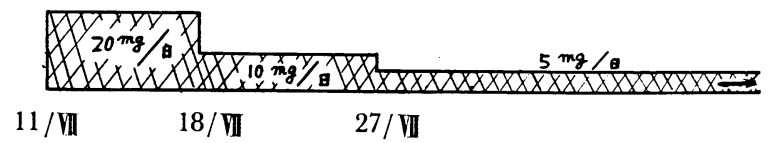

その作用はかかる同種の薬剤で以上の如くに異る点で若干の疑義をもつが，量に関しては治療上の効果よ り少くとも 1 日量 $15 \mathrm{mg}$ 以上を必要とするように思われる.

2 . 副筒, 下垂体の移植

吉富等は下垂体を, 館石等は下垂体と副腎の移植を行つて効果を見ているが，我々の例に扎いては見るべ き変化がなかつたのでしの項に打ける考察は省略する.

3.ヒヨンドロイチン硫酸, ヒヤルロニダーゼ

膠原病なるものが種々の発生原因によつて現われるにせよ，その主要変化をきたすのは紐胞間基質であり， 鞤皮症の場合にも膠原線維物質代謝の異常, 引いてはその部の間質細胞内酵素系の異常というととが密接に 結びついて考えられるのである. そして組織つ透過性を高めるものとして拡敢因子の発見以来, 基質の成分 である粘液多糖類としてその主体であるヒャルロン酸及びヒヨンドロイチン酸の作用機序並びに治療への応 用面が解明されつつある.

本症例ではヒヨンドロイチン硫酸では特別の効果は認められなかつたが，ヒャルロニダーゼでは後述のぺ ニシリンとの併用もあるが一応心悸元進, 胸部圧迫感の自覚症状と共に心臟血管系の障碍を軽減し, 皮膚軟 化への一助となつた様である.

4.ビタミン用

ビタミン $\mathrm{C}$ に関しては副島8)，長沢等がその大量使用により効果を得て抢り，我々も $500 \mathrm{mg}$ 連日静脈内 注射を行つたが格別の変つた所見を見なかつた．その作用機転に関しては間接的に副腎皮質に対する保護作 用を示すと共に，直接皮質ホルモンと共同して膠原病的変化に影響を及ばすと考えた．またビタミンCが線 維形成に重要であることからその欠乏説を重視しているが，乙れも前者のでとくこれのみで解決のつくもの

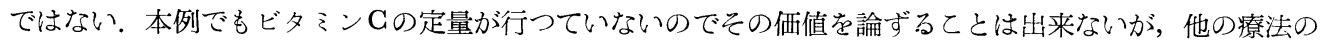
併用により一応は試みてもよい治療の一つではなからうか.

尚ビタミンDに関しては Cornbleet 等が $\mathrm{Ca}$ の代謝障碍を見る䩶皮症に扔いてその排泄増加を促すと述 べているが，本症例では第 1 表に見られる如く, 電解質の著明な変動を何れの治療の場合にも見られず，従 つてその治療効果もビタミン $\mathrm{C}$ 程には精極的に考うべきものではないようである.

5.カリクレイン

本剤は Lusschke の創案になる一種の循環ホルモンであり，ホルモン療法の範疇に付して述べるべきもの かも知れないが，恐皮症とレーノ一氏病との関連より血行障碍の存するものに著効岁りとし，伊藤，山田， Koehler ${ }^{9)}$ 等が本症に効果を認めている. 我々は第 2 表 6 亿示したようにその使用はデポカリクレイン (1cc $=40$ 生物学的単位含有) $1 \mathrm{cc}$ の連日筋肉注射にして20回に及んだ. その結果は指趾末端部の白色調は消失し 胸部圧迫感なく皮膚の軟化を来し色素沈著の減少，利尿面にも効果を見たようである。

6. ペニシリン

本症の原因に関しては他の疾患に於ける如く, 矢張り結核及び梅毒との関係が問題とされ, 就中梅毒は本 邦例に扑てもその $17 \%$ 梅毒反応陽性例をもつて打り，鞏皮症が駆梅療法によつて奏効するてとより第 1 義的な意味をもつものではなく，その治験例についても Doerr，Brunner ${ }^{10)}$ ，三浦，石田等の著効例と共に， 一方では無効例も多数報告せらてはいるが, 矢張り前述の治療と共に, 抗生物質としての利用以外にペニシ リンの血管拡張作用のある点を認めて試みるべき療法の一つとはいえよう。 
この症例に打いても血液ワ氏反応陰性であるが，疑わしい既往歴並びに配偶者にその陽性成績をみたので 駆梅療法も兼ねて水性ペニシリン 1 日 60 万単位を 17 日間総量 1020 万単位（第 2 表 5 ）を使用したところその 治療中に於て関節痛の消失, 四肢の運動制限消失し肘関節部の屈曲も可能となり, 皮膚は柔軟 elastic 亿感 じ顔面を除いては正常色に近づいた。尚指関節の変形には各々の治療とも全て影響を見ない.

以上現在に至る本例の治療並びにその効果を検討するに，鞏皮症の病的状態に扔ける種々薬剤の効果を客 観的に判定することは仲々困難である。本症例ではその臨床成績は第 1 表（I），（II）に示す如く割合にそ の恋動は少いが，第 5 図にあげるように皮膚緝織所見に於ては上皮は菱縮性であるが細胞ははば正常で真皮

第5図治療後皮膚組織標本

ヘマトキシリンエオジン染色

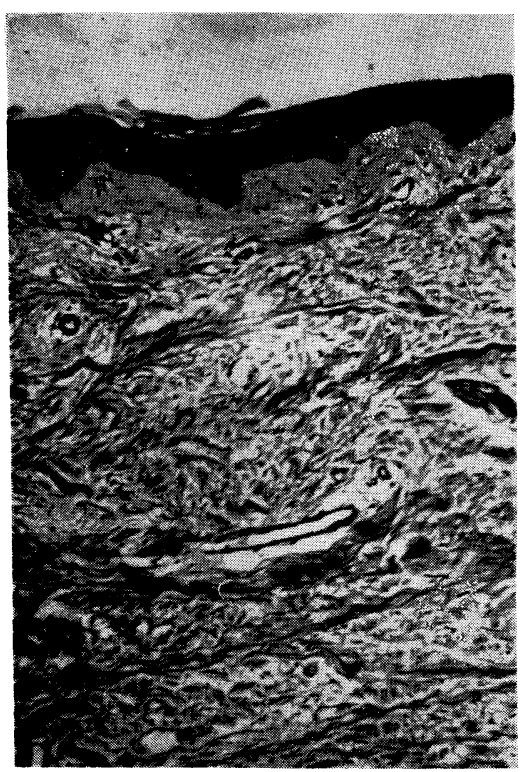

ワンギーソン染色

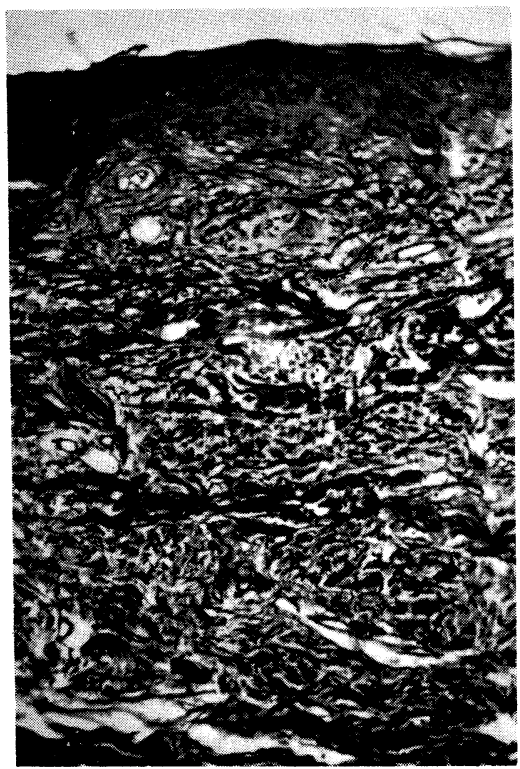

部は幾分眕原線維は太いものもあるが比較的粗徙，乳頭は低いがはぼ正常に近い単純な萎縮の像を認めるの みであり，皮虞硬化の範囲も第 1 図治療後に示したように組織所見並びに皮虐症状の改善に著しい効果を認 めた。 一方 Boyd ${ }^{111}$ の強調するようなレントゲン所見の変化，とりわけ指骨の変化に及ぼす影響は見なかつ

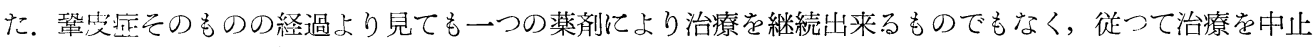
すれば必然的に悪化の傾向を来す現状にあつては，之の原因が解決をみない今日では病勢の進行を停止する のみに精一杯の有様のようである.

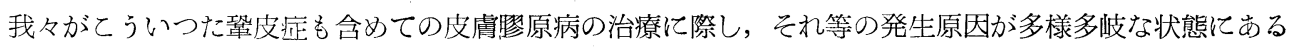
今日一体何を対象とすべきか，その取捨選択甚だ因難を来す次第であり，永久治痖をもたらすととは本症 の場合にも望み難い段階にあると思われる。

結

語

我々は一例つ汎発性鞤皮症について比較的長期にわたる钼察をする機会を得, 在来のビタミン, ペニシリ ンの原因療法に检討苍加え，更にメチコーテン，ヒヤルロニダーゼ，カリクレインにより治療し，皮膚症状， 組紪所見，並びに臨床成績の好転を認め病勢の停止を見た。 
稿を終るに臨み御校閲を睗つた山田教授並びに小林助教授に深謝するると共に，本例の治療に御援助を戴 いた皮虐科加納教授，臨床病理検査室牛島講師の御協力に深謝する。尚本論文要旨は昭和 31 年 9 月 15 日, 日 本内科学会東海地方会第46回例会に於て発表した。

\section{参考 文 献}

1) Klemperer, P ., Pollack,A .D. \& Baehr, G., : J.A.M.A. $119: 331,1942$.

2) 沖中 : 綜合臨楽. 1 :

515，昭27年. 3) Sharnoff， J.G. et al. : J.A.M.A. $145: 1230,1951$.

4) Steiner, K. \& Frank,

C. : Arch. Dermat. Syph. $65: 531,1952$.

5) 川島 : 京都医学会雑誌, $4: 2,24$, 昭28年. 日野: 彰断と治療, $44: 757$, 昭 31 年.

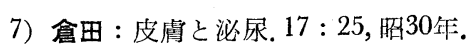

8) 福島: 治 療. $32: 1023$, 昭 25 年.

9) Koehler, H. : Arch. Dermat. Syph. $200:$ 459, 1955.

10) Brunner,

N. : Hautarzt. $3: 30,1952$.

11) Joseh, A. Boyd etal. : Arch. Int. Med. 94 : 248, 1954. 